\title{
As cabecinhas estourando, a prisāo do cientista e o cheiro da chuva: trauma, perplexidade e esperança em Não Verás País Nenhum
}

The little heads popping, the scientist's arrest and the smell of rain: trauma, perplexity and hope in Não Verás País Nenhum Ana Carolina Monay

\section{RESUMO}

Não Verás País Nenhum: entre 1976 e 1981, nascia nas páginas de Ignácio de Loyola Brandão um Brasil que, em um futuro distópico, não-mais-se-veria. Póscatástrofe ambiental, em um momento de ápice do capitalismo e sob um regime político autoritário, o não-mais-Brasil de Loyola Brandão é apresentado por Souza, que, através de um ato de rememoração, tece uma narrativa visando responder à questão máxima "como foi possível que chegássemos aqui?". O presente trabalho, tendo em perspectiva a noção de "ler em busca de Stimmung" de Hans Ulrich Gumbrecht, analisa como a narrativa de Souza apresenta o trauma, a perplexidade e a opacidade da esperança, buscando apreender, na medida do possível, algo da atmosfera do tempo e mundo de Loyola Brandão, o Brasil de fim da década de 1970 e início de 1980.

\section{PALAVRAS-CHAVE}

Trauma; Experiência; Ficção.

\section{ABSTRACT}

Não Verás País Nenhum: between 1976 and 1981, in the notebooks of Ignacio de Loyola Brandão, a country in a dystopic future was born, "that would no longer be seen". Post-environmental catastrophe, in a moment of capitalism's heyday, and under an authoritarian political regime, Loyola Brandão's non-Brazil is presented by Souza, who, through an act of remembrance, weaves a narrative aimed at answering the maximum question "how was it possible that we got here?". Thus, the present work, taking into account Hans Ulrich Gumbrecht's notion of "reading by Stimmung", seeks to analyze how Souza's narrative presents the trauma, perplexity and opacity of hope in order to apprehend, as far as possible, something of the atmosphere of the time and the world of Loyola Brandão: Brazil in the late 1970's and early 1980s.

\section{KEYWORDS}

Trauma; Experience; Fiction. 
Nascido da pena de Ignácio de Loyola Brandão, Não Verás País Nenhum tornou-se o segundo romance de grande sucesso do autor. O primeiro, Zero, escrito na Itália e publicado em 1975, tematizou a tensa relação entre a repressão e liberdade, vindo a ser censurado pelo Ministério da Justiça da ditadura militar brasileira. Já em 1981, Não Verás... é publicado, gozando de maior liberdade de circulação, tendo em vista que, sobre a década de 1980, ainda que não seja possível afirmar que a ditadura se enfraquecia, ao menos já se articulavam modos de abertura do regime.

Os objetos de inquietude do autor não puderam ser esgotados em seu primeiro romance, passando a ocupar, então, as páginas de Não Verás País Nenhum. Na obra em questão, um não-mais-Brasil foi projetado. Um país que, no futuro, não mais se veria. Pós-catástrofe ambiental, da qual não restou uma única árvore; comportando um regime político autoritário, no qual Militecnos ocupam o alto escalão do governo e as melhores posições do capital, Civiltares realizam o policiamento das ruas, Agentes Naturalmente Disfarçados podem ser quaisquer um e o Isolamento é a ameaça do temível destino dos elementos disfuncionais da sociedade; e em um momento econômico de ápice do capitalismo, quando miseráveis ocupam os Acampamentos Paupérrimos nas margens de São Paulo, empregados trabalham por um prato de comida e um copo de urina purificada por dia, e quando o domínio das multinacionais foi capaz de desfazer do Estado brasileiro e retalhar seu território, o Brasil que (não mais) se vê de Loyola Brandão foi reduzido a uma São Paulo guetizada, temerosa, quente e mefítica, que, em vez de cidadãos, produz sobreviventes.

O Brasil de Loyola se faz perceptível a partir das palavras de Souza, o narrador-personagem, um sobrevivente desse nãomais-Brasil. Em um ato de rememoração, o país-nenhum nos é apresentado através do plot twist de sua vida. O ex-professor universitário de História, aposentado compulsoriamente pela lei de segurança, é, no hoje do livro, um funcionário da burocracia 
do Estado. Como mais um hamster girando a roda da inércia, o personagem acorda todos os dias no mesmo horário, dá o mesmo bom dia à sua esposa Adelaide, toma o mesmo transporte coletivo que o leva ao trabalho, e assim, inertemente, seguiu o curso de seus dias desde os Abertos Oitenta, quando se instaurou a conjuntura supraexposta. Até que, após sentir uma coceira na mão, nela se abre um furo incrivelmente simétrico capaz de configurar-se em um acontecimento em sua vida, i. e., ponto de inflexão de onde passado e presente passam a entrelaçarem-se de uma outra forma, tornando possível o redimensionamento do campo de experiência, de sua potência de ação e do horizonte de expectativas de Souza. Então, a narrativa tecida pelo personagem, cujo subtítulo do livro classifica como "memorial descritivo", orientada pela questão máxima sobre como foi possível que se chegasse até ali, é condição de possibilidade de, através do ato de visita ao passado, promover uma conciliação com seu presente e abrir possibilidades de futuros. Além da necessidade manifesta de descrição, a narrativa se configura num processo de elaboração de traumas passados.

Diante desta breve apresentação do livro, a questão que aqui pretendo abordar se resume nas formas de apresentação da perplexidade, do trauma e da esperança na narrativa do personagem-narrador, em atenção não só aos sentidos passíveis de serem produzidos pela narrativa, mas também às sensações da ambiência do contexto de nascimento da obra. Sendo o livro capaz de emanar a atmosfera do início da década de 1980 no Brasil, através dessa análise pode ser possível perceber os pontos sensíveis que, se não unem interioridade da obra e exterioridade, implodem esses esses dois aspectos enquanto dicotomia.

Para tanto, as primeiras linhas desse trabalho tratam do contexto de escrita da obra, que aqui, a despeito de propor uma contextualização artifical, é traçado com o fito de trazer ao leitor a potência da proposição de Hans Ulrich Gumbrecht de "ler em busca de Stimmung", não exatamente como metodologia, mas 
como orientações sensíveis para "pensar hoje na realidade da literatura", abrindo ao corpo a possibilidade de percepção e de encontro com o passado como uma experiência estética (GUMBRECHT 2014, p. 09). Em seguida, imergindo no "universo da obra", apresentarei o não-mais-Brasil de Loyola Brandão, para, ao fim, compreender a dinâmica afetiva de Souza e o que dela pode ser comunicável. Tendo em vista a noção de atmosfera de Gumbrecht, se não é objetivo do trabalho ingênua ou cinicamente sobrepor literalmente os traumas, a perplexidade e a esperança de Souza aos seus contemporâneos, talvez seja possível pensar que certas dimensões de pestilência traumática, perplexidade e esperança eram afetos presentes no ar que respiravam.

\section{O Brasil que se via e sentia nas décadas de 1970 e 1980}

1981, ano de publicação de Não Verás País Nenhum. Para além das páginas de Loyola, no mundo que habita o escritor e é por ele habitado uma ditadura militar, que já durava então 17 anos, se fazia realidade. O golpe de 1964, que derrubou o governo constitucional de João Goulart, evidenciou no Brasil uma certa excepcionalidade ${ }^{1}$ que possibilitou a montagem de uma ditadura. Ao contrário dos (já desconfiáveis) acordos de entrega do governo constitucional em dois anos ${ }^{2}$, a ditadura veio a durar mais de 20 anos. Em articulação com o empresariado, os militares tomaram o controle do Estado, pondo em curso um projeto de Brasil que vinha sendo formulado no interior da Escola Superior de Guerra desde a década de 1950 (BORGES 2014).

O esforço da corporação militar em dar ao golpe um lustre institucional e, posteriormente, à própria ditadura é evidente, sobretudo pela edição do primeiro Ato Institucional dias após o golpe, em que os militares conferiam a si mesmos plenos poderes constituintes. O estado de exceção se materializava na paradoxal Constituição não soberana, não originada do pacto legal entre Estado e sociedade, não republicana e não 
democrática. Junto à cadeira da presidência, a soberania constitucional também foi usurpada.

Vladimir Safatle nos chama atenção ao que considera "uma das características mais decisivas da ditadura brasileira" (2013, p. 251):

sua legalidade aparente, ou, para ser mais preciso, sua capacidade de reduzir a legalidade à aparência. Tínhamos eleições com direito a partido de oposição, editoras que publicavam livros de Marx, Lenin, Celso Furtado, músicas de protesto, governo que assinava tratados internacionais contra a tortura, mas, no fundo, sabíamos que tudo isto estava submetido à decisão arbitrária de um poder soberano que se colocava fora do ordenamento jurídico. [...] Uma ditadura que se servia da legalidade para transformar seu poder soberano de suspender a lei, de designar terroristas, de assassinar opositores, em um arbítrio absolutamente traumático (SAFATLE 2013, p. 251 - grifo nosso).

A reoganização do Estado nessa direção foi guiada, ideologicamente, pela Doutrina de Segurança Nacional reformulada também em 1950 pela ESG. Essa versão incorpora um novo conceito de geopolítica, que compreendia que ameaças à soberania nacional poderiam ser também ameaças "ideológicas". Como não se limita a fronteiras espacialmente determinadas, esse tipo de compreensão abre o precedente para que seja interno o inimigo idealizado contra quem as Forças Armadas devem lutar por ameaçar a Segurança Nacional (BORGES 2014). Embasada nessa DSN, a Lei de Segurança Nacional de 1967 prescreveu uma série de ações passíveis de criminalização, tais como a censura, a tortura, sequestros, desaparecimentos forçados, execuções sumárias. A violação dos Direitos Humanos foi sistematizada, encontrando brecha para existir no coração do Estado, na legislação de exceção.

Se, por um lado, uma concepção estreita de vítimas da ditadura compreende pessoas as quais suas vidas foram afetadas pela intervenção direta de algum agente do Estado encarnado; por outro, é possível compreender que o clima geral de arbitrariedade e violência - que, no limite, sustenta a faceta 
autoritária do Estado - é capaz de envolver a todos, embora em aspectos e nuances diferentes entre si. Ratifico as palavras de Safatle: o "arbítrio absolutamente traumático", originado do uso da legalidade pela ditadura, é caracterizado pela mescla entre direito e ausência de direito, lei e fora da lei (SAFATLE 2013, p. 251). É justamente por conta da manutenção de um aparato normativo que a suspensão arbitrária desse aparato gera uma situação de insegurança, a princípio jurídica, mas que se amplia largamente, se estendendo à integridade física e moral.

Vale, nesse ponto, mencionar as considerações sobre a relação entre repressão e poder identificadas por Pilar Calveiro, em Poder e Desaparecimento (2013), e sobre a faceta revelada e ocultada do/pelo poder. Segundo Pilar,

não há poder sem repressão, mas, mais do que isso, é possível afirmar que a repressão é, de fato, a alma do poder. As formas que ele adota revelam sua mais profunda intimidade que, precisamente por ser capaz de escancarar o poder, torná-lo óbvio, se mantém secreta, oculta, negada. (CALVEIRO 2013, p. 37-38)

A partir dessa consideração, a autora compreende que o "traje de domingo" do poder militar, "que aparece nos desfiles, no sistema penal, no exercício legítimo da violência," embora revelem "um rosto rígido e autoritário, [é] coberto por um verniz de limpeza, altivez e brilhantismo", se configurando na parte mostrável do poder. Entretanto, uma outra, vergonhosa, é negada: ela aparece "nos assassinatos políticos, nas práticas de tortura, nas negociatas, na corrupção" (CALVEIRO 2013, p. 37-38).

Ora, nas descrições dos campos de extermínio da Argentina, mantendo a interseção entre o que do poder é revelado, e como isso que é revelado oculta uma face do poder, e como o que é ocultado revela a outra face negada, a autora ressalta que os campos funcionavam dissimulados em dependências militares, mantendo proximidade para/com a vida cotidiana das pessoas. "Tratava-se de um segredo guardado sem muito 
empenho" (CALVEIRO 2013, p. 53). Embora Pilar Calveiro analisasse a ditadura argentina, é possível fazer ilações com a realidade brasileira. Relembro aqui o testemunho de Dulce Pandolfi à Comissão Nacional e Estadual da Verdade, quando denuncia a noção de "porões da ditadura", revelando que a tortura acontecia não em porões, mas na sala de estar das dependências oficiais.

Naquela noite, no dia 20 de agosto de 1970, no momento em que entrei no quartel da Polícia do Exército [...] eu ouvi uma frase que até hoje ecoa forte nos meus ouvidos: 'aqui não existe Deus, nem padre, nem família'. [...] Diferentemente do que muitos dizem, aquele lugar não era um porão da ditadura, um local clandestino. Embora ali não existisse nem Deus, nem padre, nem família, eu estava em uma dependência oficial do Exército brasileiro, uma instituição que funcionava a todo vapor, com todos os seus rituais, seus símbolos, seus hinos, sua rotina $^{3}$ (PANDOLFI 2013, NP).

Se, de um modo, não era estratégico apresentar toda a face vergonhosa do poder; de outro, algo que fosse capaz de dissuadir potenciais oponentes deveria ser relevado. "De fato, para disseminar o terror, cujo efeito imediato é o silêncio e a inação, é preciso mostrar uma fração daquilo que permanece oculto" (CALVEIRO 2013, p. 53).

Ao fim da década de 1970, uma lei de anistia começa a oferecer os contornos da já falada abertura do regime. Porém, ao contrário dos anseios das ruas por uma anistia "ampla, geral e irrestrita", a lei de anistia acabou se configurando uma autoanistia para os militares, e a permanência de formas variadas de condenação para os presos políticos (GAGNEBIN 2010). Como consequência desse processo de anistia, destacase a tentativa de silenciamento das vozes das vítimas, às quais foi negada uma justiça de transição completa, que incluiria, dentre outros fatores, a abertura de um espaço jurídico-político aos moldes das Comissões da Verdade que ocorriam nos outros países violadores dos Direitos Humanos. Uma democracia vinha (re)nascendo, sem que o Estado fizesse uma autocrítica sobre a violação sistemática dos Direitos Humanos (CALIL 2012).
3. disponível em: https:// www. youtube.com/ watch? $v=Z$ wyKtFdZrKK. Acessado em 28 jul. 2017. 
Já no meio da década, os anseios pelas Diretas, Já! foram solapados pela emenda Dante de Oliveira, que determinou que o civil a suceder os militares seria eleito indiretamente. A morte precoce de Tancredo Neves, emedebista eleito indiretamente pelo Colégio Eleitoral, levou José Sarney (PFL), o vice da chapa, à presidência da República. Se a década de 1980 convivia ainda com a pestilência - tanto por conta dos anos que ainda comportavam a ditadura, quanto de suas heranças traumáticas que rizomaticamente penetravam a nascente democracia -, e com a perplexidade - tanto legada da década de 1970 quanto suas atualizações frente às derrotas inesperadas no momento de abertura -; de outra maneira as possibilidades de abertura do regime traziam a esperança.

\section{O lugar dos afetos e a leitura por Stimmung}

Em vídeo de divulgação de seu mais recente livro $O$ circuito dos afetos: Corpos Políticos, Desamparo e o Fim do Indivíduo, de 2015, Vladimir Safatle (2016), em diálogo com a psicanalista Maria Rita Kehl, analisa os afetos do medo e da esperança e sua relação com a condição de possibilidade de ação. ${ }^{4}$ Segundo o filósofo, medo e esperança são afetos provenientes da forma das relações que os homens estabelecem com o tempo futuro. O tempo é vivido, sob esses afetos, como expectativa. Dos dois modos, há a projeção de um futuro que deve ocorrer, e é essa projeção que permite aos indivíduos saberem como agir. Ambos afetos são antagonicamente complementares: quem tem esperança, também tem medo de que o esperado não ocorra. Pode-se afirmar que o medo ainda atingia os mais descrentes em relação à democracia nascente, mas a Constituição de 1988 e os "novos tempos" traziam também esperança.

Safatle (2016), nessa mesma ocasião, comentou sobre a relação entre os afetos e a política:

Como se a condição da política [na democracia] fosse o esfriamento das paixões. Você precisa criar um espaço que seja marcado pela procura pelo melhor argumento, uma

4. Publicado em $26 / 03 / 2016$. Disponível em: ht t ps: / / w w w . youtube.com/ watch? $v=g n 4 A-$ 6pps5k. Acessado em 28 jul. 2017. 
argumentação racional, que seria então esse diálogo livre do peso das paixões. Essa visão tende a vincular os afetos à dimensão do irracional (SAFATLE 2017).

Segundo o autor, a política seria marcada pela busca da fala não afetada. Ora, não é preciso muito esforço para traçar paralelos com a relação entre método, objetividade e verdade na construção das ciências humanas. Para reafirmar um estatuto de cientificidade, desvios considerados subjetivistas foram afastados de todo enunciado que se pretendia científico. Além disso, a noção de fato confundiu-se com verdade, de modo que o empirismo se tornou outro critério legitimador do metadiscurso científico nas humanidades (BENZAQUEM 1992). Como consequência óbvia, as questões afetivas não se configuravam como objeto de estudo para as ciências, devido a sua impossibilidade natural de serem submetidas à um método científico que se construía com base na noção de verdade como veritas, empirismo, objetividade.

Entretanto, no final do século $X X$, as ciências humanas passaram por um ponto de inflexão geral, que concentrou as discussões sobre as possibilidades de acesso a um mundo real, e, consequentemente, de construir enunciados objetivos sobre esse mundo. Na disciplina histórica, duas tradições surgiram: a neohistoricista, cuja marca principal é a noção da impossibilidade de acesso a qualquer forma real do passado, cabendo aos historiadores e historiadoras construírem enunciados representativos cujo efeito prático no presente seja um critério. E a outra, a fenomonológica-hermenêutica, herdeira dos estudos de Heidegger, compreendendo que a possibilidade de construção de enunciados objetivos sobre a realidade é impossível, não porque a realidade é inacessível, mas porque a relação que homem e o mundo estabelecem é de profunda intimidade, não existindo, assim, distância e observação excêntrica (RANGEL; ARAUJO 2015).

Hans Ulrich Gumbrecht, tão herdeiro da tradição heideggeriana quanto crítico da metafísica, advoga pelo estabelecimento de uma relação com o mundo que reconheça 
a sua materialidade como presença, bem como critica a falta de espaço nas ciências para estudo dessa relação. Atentando para "o potencial escondido da literatura", em Atmosfera, Ambiência, Stimmung (2014) o autor, ao trazer a discussão para o campo dos estudos literários, identifica que há dois pressupostos mutuamente exclusivos que configuram o que chama de ontologia da literatura - ou seja, "o conjunto de modos fundamentais como os textos literários - enquanto fatos materiais e enquanto mundos de sentido - se relacionam com as realidades que existem fora deles." (GUMBRECHT 2014, p. 10). Esses dois pressupostos seriam o desconstrucionismo, que, segundo Gumbrecht, "sempre pertenceu àquela 'virada linguística' da filosofia. Isso significou - e, para os seus defensores, continua a significar - que não pode existir contato entre a linguagem e a realidade que existe fora dela" e, de outra maneira, os estudos culturais, que

pelo menos em parte, eles compartilham os pressupostos metodológicos (talvez fosse melhor dizer: ideológicos) do marxismo, que consideram seu precursor e seu ponto de partida. Ao contrário do desconstrucionismo, os estudos culturais - tal como surgiram na Grã-Bretanha e vieram a transformar-se, na Alemanha, em Kulturwissenscbaften (sem grandes diferenças) nunca foram céticos quanto à relação da literatura com realidades extralinguísticas. Quando muito, os pesquisadores nessa área de estudos fundiram de tal maneira sua fé na validade da pesquisa quantitativa e empírica e sua atitude de despreocupação relativa à epistemología, que os modestos resultados filosóficos desta convergência fazem o desconstrucionismo, com sua rejeição do referente, parecer quase sedutor, ao menos em termos filosóficos (GUMBRECHT 2014, p. 10-11).

Ainda segundo o autor, o caráter mutuamente exclusivo de ambas posições pode levar a uma estagnação do campo, sendo necessário, segundo ele, uma terceira posição que, não por acaso, será sugestionada pelo autor.

A palavra alemã Stimmung (muito difícil de traduzir) exemplifica um "terceiro" que eu gostaria de defender. Por analogia com a noção de "ler para conhecer a intriga", desenvolvida por Peter Brooks já há alguns anos, eu gostaria de propor a ideia de que os intérpretes e os historiadores da literatura leem com a atenção 
voltada ao Stimmung. Uma das razões pelas quais recomendo tal abordagem é que esta é a orientação de grande número de leitores não profissionais (que não estão - e, claro, não têm de estar - conscientes desse fato) (GUMBRECHT 2014, p. 11-12).

Gumbrecht enfrenta uma contradição intrínseca à sua própria questão, e quaisquer outros que propuserem semelhante caminho enfrentarão. O autor é, de certa forma, apanhado num círculo que Derrida apresenta em $A$ Estrutura, o Signo e o Jogo no Discurso das Ciências Humanas:

Este círculo é único e de certa forma da relação entre a história da metafísica e a destruição da história da metafísica: não tem nenhum sentido abandonar os conceitos da metafísica para abalar a metafísica; não dispomos de nenhuma linguagem - de nenhuma sintaxe e de nenhum léxico - que seja estranho a essa história; não podemos enunciar nenhuma proposição destruidora que não se tenha já visto obrigada a escorregar para a forma, para a lógica e para as postulações implícitas daquilo mesmo que gostaria de contestar (DERRIDA 1971, p. 233).

Ora, na crítica à tradição metafísica e na proposta de leitura em busca de Stimmung, Gumbrecht inevitavelmente recorre a um vocabulário pertencente à tradição que pretende contrapor. É evidente que muito do inominável que, como ressaltou Derrida (1971), só o é por se tratar de um fenômeno que não pôde ser encaixado dentro dos tradicionais quadros conceituais, hoje já possui um nome. Talvez seja o caso de Stimmung. Entretanto, a compreensão de Stimmung e seu potencial só se torna inteligível e só pode ser reconhecida pelo contraste com a tradição.

Devido aos imprecisos contornos do conceito em questão - se é que Gumbrecht pretende transformar em um conceito, caindo em mais uma das contradições inevitáveis pela falta de ferramentas disponíveis -, cabe reiterar as próprias palavras do autor sobre Stimmung.

Só em alemão a palavra se reúne, a Stimme e a stimmen. A primeira significa "voz" ; a segunda, " afinar um instrumento musical"; por extensão, stimmen significa também "estar correto". Tal como é sugerido pelo afinar de um instrumento 
musical, os estados de espírito e as atmosferas específicas são experimentados num continuum, como escalas de música. [...] Interessa-me muito a componente de sentido que relaciona Stimmung com as notas musicais e com escutar os sons. E bem sabido que não escutamos apenas com os ouvidos interno e externo. O sentido da audição é uma complexa forma de comportamento que envolve todo o corpo. A pele, assim como modalidades de percepção baseadas no tato, tem funções muito importantes. Cada tom percebido é, claro, uma forma de realidade física (ainda que invisível) que " acontece" aos nossos corpos e que, ao mesmo tempo, os "envolve". Outra dimensão da realidade que acontece aos nossos corpos de modo semelhante é o clima atmosférico. Precisamente por isso, muitas vezes as referências à música e ao tempo atmosférico aparecem na literatura quando os textos tornam presentes - ou começam a refletir sobre - os estados de espírito e as atmosferas. Ser afetado pelo som ou pelo clima atmosférico é uma das formas de experiência mais fáceis e menos intrusivas, mas é, fisicamente, um encontro (no sentido literal de estar-emcontra: confrontar) muito concreto com nosso ambiente físico (GUMBRECHT 2014, p. 12-13 - grifo nosso).

Contra a possível crítica da definição de Stimmung como uma metáfora, Gumbrecht responde: "Mas o meu argumento é que esses tons, atmosferas e Stimmungen não existem nunca completamente independentes das componentes materiais das obras" (GUMBRECHT 2014, p. 13-14), ou seja, na sua proposta, o potencial escondido seria o que emerge na Literatura, mas que não é só sentido, tampouco somente representação, é presença. O efeito de presença aconteceria pela dissolução entre forma e conteúdo. A forma diz do conteúdo; forma é conteúdo, e não existe conteúdo disforme.

\section{O nāo-mais-Brasil - E os afetos disponíveis para leitura}

"Mefítico. O fedor vem dos cadáveres, do lixo e excrementos que se amontoam além dos Círculos Oficiais Permitidos, para lá dos Acampamentos Paupérrimos" (BRANDÃO 1982, p. 11). Se essas palavras, as primeiras do livro, já podem causar por si a sensação do desconforto em respirar um ar que fede a cadáver, lixo e excrementos, a potência delas é ampliada 
quando contrastadas com a epígrafe escolhida por Ignácio de Loyola Brandão: "y llegando yo aqui a este cabo vino el olor tan bueno y suave de flores o arboles de la tierra, que era la cosa mas dulce del mundo"s, frase creditada a Cristóvão Colombo, de 1503, proferida diante do cabo Hermoso. Essa coisa mais doce do mundo, em um não-mais-país que não mais possui árvore alguma, se tornou produto artificial, comprimido em uma lata de spray a ser comercializado. Cheiro de folha seca, folha podre úmida, bosta de vaca, eucalipto no fim de tarde, flores, verduras, serraria depois de cortar troncos de cedro, alfazema, jasmim, jatobá aberto, algodãozinho, papel novo, jaca, chá mate[...] Cheiros fabricados e vendáveis. Produtos feito de cheiros que não mais existem. Cheiros de memória.

Junto ao fedor, o calor de um "sol violento demais [que] corrói e apodrece a carne em poucas horas" (BRANDÃO 1982, p. 11). A vida verde foi extinta. O deserto da Amazônia, considerada a nona maravilha do mundo, avança rumo ao mar. Os últimos animais existentes, além dos ratos que são pragas da cidade, sobreviviam em uma pequena reserva secreta mantida por também secretos cientistas. Que carne a violência desse sol que queima no cinza dos concretos armados é capaz de apodrecer? Na passagem citada, a referência direta é à carne cadavérica. Mas será que a atmosfera pestilencial sobre a qual vivem os vivos não os apodrece também?

Os rios secaram. Urina reciclada é o que tem de disponível para solucionar a sede. "O corpo melado. A roupa grudada na pele. Ofegante" (BRANDÃO 1982, p. 91). Camisas, vestidos e paletós sintéticos: o suor exalado na estufa entre a roupa e a pele, o suor mefítico que brota da pele de corpos que se alimentam de comidas factícias, artificiais, produzidas por indústrias químicas governamentais e que de líquido ingerem somente urina processada[...] Fedor, calor e sede. O sol também apodrece os vivos.

Mefítica, quente, sedenta e lenta. Como forma de minimizar o efeito do calor e da sede, os sobreviventes desta São Paulo evitam mover-se rapidamente.
5. "E chegando eu aqui a este cabo [me] veio o cheiro tão bom e suave de flores ou árvores da terra, que era a coisa mais doce do mundo." (tradução livre). 
Os prédios concentram o mormaço, as filas de circulação caminham indolentes. Como era engraçado o tempo em que todo mundo andava apressado em São Paulo, aos encontrões, esbarros. No entanto, a irritação no rosto e dentro da gente é igual. Por causa desse abafamento constante, interminável. O povo se move em câmera lenta, como se vivesse dentro de um efeito especial em cinema. Cabeças baixas, respirando mal, seguindo as filas, entrando e saindo de edifícios. Poupando energia para conseguir suportar um pouco mais, e conseguir chegar ao fim do dia (BRANDÃO 1982, p. 91-92).

A fim de racionalizar o deslocamento dos citadinos, o Esquema guetizou a cidade. Os bairros foram separados por critérios de classe, categorias sociais, profissões e hierarquias no Esquema, e o trânsito entre um e outro não era livre; através de fichas de circulação, só era possível circular em determinados espaços. "A ficha aponta por onde posso andar, os caminhos a percorrer, bairros autorizados, por que lado da calçada circular, condução a tomar" (BRANDÃO 1982, p. 18).

Preso nessa rotina inerte estava Souza, narradorpersonagem da obra. Fazia mais ou menos 30 anos, todos os dias acordava no mesmo horário, e bebia com sua esposa Adelaide o mesmo café factício. Ele colocava seu chapéu, acariciava o ombro esquerdo de Adelaide, consultava o relógio e apanhava seu ônibus S-7.58 pontualmente, junto a todas as pessoas que seguiam semelhante rotina. Era essa a forma de instrumentalização do tempo: o tempo era o tempo de um só dia. Acordar no mesmo horário, recorrer o mesmo coletivo, realizar o mesmo trabalho.

Souza era um funcionário do Estado, conferia tediosamente papéis ao longo de sua jornada. O excesso de perguntas intragáveis para a Segurança Nacional em suas aulas levou a direção da universidade onde lecionava a questionar que tipo de aula o professor vinha construindo com seus alunos, o que Ihe custou uma aposentadoria compulsória. Como exemplo, era perigoso citar a Era da Grande Locupletação, momento seguido dos Abertos Oitenta, quando a concentração de renda foi extrema, enriquecendo os pouquíssimos ricos e levando 
à miséria os muitíssimos pobres. De acordo com os círculos oficiais do Novo Exército, a Era da Grande Locupletação não passava de um mito negativista, subversivo e perigoso. E, bem, o fechamento dos arquivos oficiais ao público em geral e aos cientistas tornava impossível o acesso à documentação oficial, que comprovaria a veracidade dessa Era.

Hipóteses negativas, subversivas, perigosas. Mas não só esse era o grande perigo. Os Agentes Naturalmente Disfarçados poderiam ser quaisquer um, e os Civiltares, uma milícia formada por ex-militares da linha dura e civis radicais, que contava com a negligência consciente e apoio do Esquema, cuidavam da chamada Segurança Pública. Eram os mestres em atirar e perguntar depois; qualquer atitude considerada suspeita podia conduzir o sujeito ao temível Isolamento.

No alto escalão do governo e nos melhores cargos do país - fundidos, aqui, o Estado e as empresas - estavam os Militecnos. Eram militares, mas tinham acesso exclusivo à formação universitária. Claro, após a perseguição aos cientistas, só restou para o ensino universitário o que podia ser útil. Sendo de uma geração pós-acidente do Reator Nuclear, a geração dos Militecnos não tinha o cérebro normal.

Ficou demonstrado pelos cientistas. Foi mais uma das razões que os tornaram marginalizados. Provou-se que os Militecnos sofreram metamorfoses em seu organismo. O cérebro ficou afetado. Perdeu parte da memória. As emoções foram eliminadas. Tornaram-se serenamente calculistas (BRANDÃO 1982, p. 29).

Como no título de tal secção da obra, "nas suas divagações, Souza vê que tem sorte, pois ainda possui memória, ao contrário dos Militecnos, que já perderam suas faculdades humanas" (BRANDÃO 1982, p. 24). Memória está, aqui, diretamente relacionada à condição humana. Ora, Souza mesmo identificou:

Sou lúcido para saber que o controle total, rígido, dos meios de comunicação, aliado à Intensa Propaganda Oficial, IPO, amorteceu as mentes. De tal modo que esta emergência em que vivemos passou a ser considerada normal. A nossa 
memória é admirável, porque este passado é recente. E nos esquecemos. Tudo se precipitou, rápido demais. [...] Se analisarmos a história, vamos concluir que o nível de vida do brasileiro baixou a zero. Todos querem sobreviver (BRANDÃO 1982, p. 30-31 - grifos nossos).

Quanto da sobrevivência reduz a vida? No eterno presente da manutenção imediata da sobrevida, de trabalhadores que trabalharam por um prato de comida e um copo de urina decantada, de censura e repressão, existe espaço para a memória?

Cito, aqui, algumas "Palavras Prévias" de Fernando Catroga, autor de Memória, História e Historiografia (2015):

O passo que o homem [e as mulheres] dá[/ão] para a frente tem na pegada anterior a sua condição de possibilidade. Trespassado de tempo, o seu caminhar vai deixando traços no ecrã branco de Cronos [...]. Seja como for, eles são sinais que impedem de ser só presente ou só futuro. Dir-se-ia que vão, colados às solas de seus pés como sombras que, se ficam para trás, o sol da vida também projeta para adiante (CATROGA 2005, p. 07).

Isto é, seporumlado há sombras do passado que ficampara trás no solado dos pés de quem caminha, embora quem caminha não caminhe sempre para frente, no momento de incidência o sol - e esse que é da vida - projeta sua luz para a frente. Como condição de memória, então, entende-se que sombras devem ser deixadas para trás, sendo essa a única possibilidade de projeção do sol da vida. Um sol que incidisse sem deixar sombras fincaria o homem em um eterno presente, ao passo que um sol que se projetasse para trás iluminaria somente o que passou, deixando à frente sombras que turvam os sentidos e impossibilitam a caminhada. Seriam esses ainda sol? Sol da vida? Ora, o violento sol que racha a cabeça dos sobreviventes dessa São Paulo os encerra no presente. Sem lembrar, sem esquecer, sem agir. Eterno presente atualizado.

Por outro lado, a condição de projeção do sol da vida é deixar sombras. 
Tal força [a do esquecimento] não é vis inertiae [força da inércia], como acreditam os superficiais; ao contrário, é um poder ativo de obstrução, e, no sentido mais rigoroso da palavra, positivo, ao que se atribui o fato de que o que é vivido, experimentado e assumido apenas por nós, não penetra em nossa consciência em estado de digestão (poderia ser chamado de assimilação psíquica) (NIETZSCHE 2006, p. 30).

Seria importante para Nietzsche (2006), autor dessa afirmação,

um pouco de paz, um pouco de tábula rasa da consciência, criando outra vez um lugar para algo novo, e acima de tudo para as funções e funcionários mais nobres, para o reger, antever, predeterminar [...] - esta é a utilidade, como disse, do esquecimento ativo, como um porteiro ou zelador da ordem psíquica, da calma, da etiqueta, como que logo se vê que não poderia haver felicidade, alegria, esperança, orgulho, presente, sem o esquecimento (NIETZSCHE 2006, p. 30 - grifo nosso).

"Homem memorioso imbuído de expectativas", como diria Catroga (2015, p. 08), ou um fazedor de promessas, nas palavras de Nietzsche (2006), a vida é possibilitada não só pelo que se lembra, mas também pelo que se esquece.

Ora, Souza também havia sido preso nas rédeas do imediatismo. Como outros, vivia girando a roda, cumprindo cada dia como se fosse o único, preso na inércia de um cotidiano altamente controlado pelo Esquema. Onde estavam as brechas para sair do moto-contínuo? Segundo Safatle (2016), em um dado momento, a consciência deve se angustiar. A angústia representa o esgotamento de uma forma de (no caso, sobre)vida. E, através dela, é possível redimensionar o campo da experiência; ou seja, redimensionar passado e presente, e abrir possibilidades de futuros. O momento da angústia é momento do desabamento das imagens de mundo e de passado, fixadas até então. O desabamento dessas imagens permite tanto criar novas, quanto reposicionar as mais cristalizadas. Angústia é, para Safatle (2016), um afeto que detém potência de transformação. A roda girava sem sair do lugar. "Produzindo o quê?" pergunta Souza.

O vazio. O moto-contínuo. Funcionaria a vida inteira, sem parar. A menos que alguém interrompesse. Se ninguém impede, as 
coisas continuam eternizadas. É sempre preciso intervenção, que alguém se interponha, se transforme em obstáculo à repetição (BRANDÃO 1982, p. 95).

No caso de Souza e de seus leitores, a angústia é gerada a partir de um furo que aparece em sua mão, capaz de reconfigurar toda a sua vida. É a partir desse furo que Souza começa a narrar-se, narrar São Paulo, narrar seu passado e presente, e narrar possíveis futuros.

\section{Trauma, perplexidade e esperança como afetos compartilháveis entre exterior e interior da obra}

Brechas: o furo tem o poder de desautomatizar a vida de Souza, e colocar-Ihe a pergunta: "como chegamos até aqui?". De certa maneira, essa é pergunta que conduz a narrativa memorialístia de Souza, tendo em conta o constante e inevitável trânsito que amalgama o indivíduo - como "eu" cheguei até aqui - e o coletivo - como nós chegamos até aqui.

Ainda de início, Souza relata o estranhamento nesse olhar para o passado e a busca por si mesmo. Diz ele:

Fechado por placas pregadas por fora. Assim me sinto. Contando os dias, detalhando meus passos. Sensação de que me observo em microscópio, aumentando dezenas de vezes. Quantas vezes não reconheço este Souza que desliza num líquido viscoso. Sou, todavia não pode ser eu (BRANDÃO 1982, p. 17).

Buscando a si-mesmidade no passado, as imagens que se projetam entre as duas estruturas temporais não são capazes de se sobreporem: o Souza do passado não é idêntico ao Souza do presente. Agregada à pergunta máxima sobre "como chegamos até aqui" está, justamente, o desabamento das imagens estáveis do passado e a consequente impossibilidade de articulação dessas com o seu presente. Como articular um passado incompreensível a um presente recém-desperto como tal?

Lutei para pagar casa, aceitei a troca pelo apartamento, briguei para arranjar emprego, aceitei o que me deram, apavorado com a perspectiva de um não-futuro. E foi exatamente ao 
não-presente que cheguei. Olhando para trás, vejo que vivi em um não-passado. E a conclusão é simplesmente terrível. Sim, porque um homem que atravessou um não-passado e caiu dentro de um não-presente, este homem não existe. Aqui estou, posso me tocar, me pegar. Penso, reflito, concluo: me vejo inteiro, mas não me reflito, não há imagem (BRANDÃO 1982, p. 181).

O presente duro de Souza o fez buscar não olhar para o passado. "Há quantos anos penso assim: este é meu cotidiano, tenho que vivê-lo da melhor forma possível. Todo mundo pensa assim, por isso as coisas andam como andam" (BRANDÃO 1982 , p. 181). Memórias duras, se pudessem, deveriam ser evitadas, já que o presente, composto por um cotidiano feito de cenas que "nem foram feitas para suportar", teria que ser carregado, pois "são o cotidiano, feijão com arroz" (BRANDÃo 1982 , p. 181). Era inevitável. Além de esvaziar o presente, disse Souza que "para eliminar o sofrimento, elimina-se a memória. Uma cirurgia aparentemente simples, única solução", mas que, percebe ele, não é possível: "eu não consigo. Tudo é vivo dentro de mim. Agitado" (BRANDÃO 1982, p. 170). A re-visita ao passado busca, mais ou menos voluntariamente, promover essa ligação interrompida.

"Onde está nosso filho? Nem sei se tivemos. Pode parecer absurdo, mas é verdade. Podem acreditar. Pela minha honra. Tudo se confunde na minha cabeça, o que foi e o que devia ser. O que era realmente e aquilo que eu gostaria que fosse". (BRANDÃO 1982, p. 15). Uma realidade que, se nos dissessem com verdade, "ultrapassariam os limites do inacreditável" (BRANDÃO 1982, p. 189). Dada a loucura manifesta do que se apresentava como normal na vida de Souza, o senso de credulidade se encontra, em sua narrativa, abalado, de modo que nem seus interlocutores, tampouco ele mesmo, têm clareza do que realmente aconteceu e do que é produto de sua (in)consciência fora do campo da experiência factível. Na Era das Grandes Esterilizações, depois de muitos abortos provocados pelo Esquema através da intoxicação de alimentos para mulheres, teria Souza e Adelaide de fato tido um filho? 
Adelaide sonhava, repetidas vezes com coisas que Souza classificava como "coisas que devem ser esquecidas", cuja única sugestão possível seria sepultá-las como um passado duro dado o inferno que viviam como cotidianidade.

O navio afundava num mar terrível. Não havia tempestade alguma, nem vento, só o silêncio. Sabe o que me congelava? O ruído das lâmpadas quentes estourando, quando tocavam a água fria. Os cordões de lâmpadas se arrebentavam, soltando uma fumacinha branca. O mar foi ficando escuro, escuro, até que a última lâmpada se apagou. Eu, sem enxergar nada, só ouvindo aquelas explosões. Nem mesmo um gemido. Elas morreram todas, não morreram, Souza? Você vai ter que me contar uma hora. Será que não era o barulho das cabecinhas estourando? (BRANDÃO 1982, p. 15 - grifo nosso).

Mesmo quebrando o pacto de silêncio, Adelaide retornava ao assunto que remontava a um episódio no qual todas as crianças daquele não-Brasil, inclusive um suposto filho do casal - suposto, pois, tamanha inverossimilhança, a realidade de tal episódio é capaz de confundir - foram postas em um navio e enviadas não se sabe para onde: se para algum lugar ou se para a morte. A dúvida, enquanto um ponto solto na história de vida do casal, por um lado ainda alimentava a esperança de um contato ou do retorno do suposto filho. Porém, em contrapartida, tendo em vista a inverossimilhança do real, essa dúvida era como um fundamento.

No subtítulo do livro encontramos "memorial descritivo". De fato, tem muito de descritivo: assim é possível conhecer o país-que-não-se-veria. Mas tem de traumático também. Primeiramente é necessário destacar a ambivalência do trauma; é tanto, e a um só tempo, evento gerador (traumático) e seus efeitos (traumáticos) prolongados. De acordo com o Vocabulário da Psicanálise - Laplanche e Pontalis (2001), que sistematizou os estudos de Freud, o trauma pode ser definido como a recepção não adequada pelo sujeito de um evento de excessiva intensidade, gerando, assim, uma patogênese psíquica que também é chamada trauma. Em outros termos, um evento pode gerar um fluxo demasiado de excitação, cujo sujeito não 
tolera psiquicamente receber, organizar e elaborar, i.e., tornar a experiência pretérita assunto tematizável e articulável a outras experiências da história psicológica individual.

A ambivalência evento gerador e efeitos, na realidade, é dada pela própria quebra do tempo linear intrínseca à experiência traumática. Em vez de buscar compreender o trauma na chave clássica de causa-efeito - o que custa tensionar a linguagem a fim de demonstrar que essas duas chaves são insuficientes para dar conta do fenômeno -, talvez fosse mais adequado apostar em uma forma circular de compreensão: no trauma, evento gerador e efeitos são cíclicos, sem começo e fim de um e outro; eles se fundem e se revelam fundidos ao mesmo tempo. A noção do pretérito não tematizado, não significado e articulado com o(s) passado(s) - portanto, não elaborado - materializa a imagem do "passado que não passa". O recalque de uma experiência - quero dizer: na dificuldade do sujeito de lidar com os afetos da experiência traumática, com o objetivo de se defender da desarticulação psíquica, o sujeito, inconscientemente, "esconde" aquela experiência da sua história individual, tornando a lembrança recalcada - não provoca o apagamento dessa lembrança, como pretendeu Souza, mas somente seu encobrimento.

Ora, se a lembrança recalcada não é apagada, ela retorna. Há duas formas de emergência do recalcado: na primeira forma, chamada de "compulsão pela repetição", o sujeito, sem identificar o protótipo original da experiência traumática passada, se coloca em situações que repetem a constelação da situação pretérita geradora do trauma acreditando ser novidade. E, de outro modo, o chamado acting out, ou "atuação", se configura na irrupção brusca do afeto gerado no momento do trauma em momentos outros, ocasionando no sujeito a revivência no presente de uma experiência passada (LAPLANCHE; PONTALIS 2001). Souza teme: "Se eu soltar minha cabeça, as recordações disparam, memória afetiva descontrolada" (BRANDÃO 1982, p. 178). Em ambos os casos é notável a implosão das estruturas temporais. 0 passado existe no trauma como adjetivo, qualificando uma determinada 
experiência, mas que não se substantivou e se tornou o/um passado. Esse passado adjetivo que não se tornou memória assalta o presente, descaracterizando-o: esse é um presente que ou não se reconhece como tal, no caso do acting out, ou só reconhece a si mesmo, como na repetição. Um passado não tematizado e um presente que se confunde em si mesmo na vivência de um sujeito o impossibilita de articular um futuro; esse, na situação traumática, toma forma no modo da repetição inconsciente.

Uma explosão rápida, seca. Como a de uma lâmpada quente mergulhada em água gelada. Estourando com o barulho abafada. Dolorosas lâmpadas elétricas se apagando no meio de um mar gelado. Cordões de lâmpadas festivas apagando-se. [...] Lâmpadas coloridas. Surgem às centenas, milhares. Uma festa. Tem de ser, porque consigo ouvir perfeitamente os gritos. Estranho, não há música. Gritos em pleno silêncio, e o ruído das águas. Agitadas. Porque agitadas se em volta é tranquilo? Os estouros secos sucedem. Tudo o que vejo é imensidão de água, barulho de ondas rolando, batendo. As lâmpadas se apagam e não descubro se água fustiga as rochas. [...] Há um casco escuro. Um casco de navio que se afunda. A imagem é muito clara, não entendo. Jamais estive no mar, nunca viajei de navio. Navio, lâmpadas estourando, gritos, explosões como se fossem cabeças. Meus Deus, é o sonho de Adelaide. Delírio meu, não pode ser. Estou mergulhado em pleno sonho, e num sonho que não é meu. Cada manhã ela me contava, eu me apavorava. Não queria admitir, por nada. Nem podia pensar que o navio de nossas crianças pudesse ter afundado. Estou seguro que chegou a um porto, as crianças desembarcaram. Hoje devem ser adultos, vivem suas vidas (BRANDÃO 1982, p. 340).

Se o trauma está ligado à atualização de um complexo de afetos do passado no presente decorrente de uma experiência geradora, a perplexidade é um afeto - ou bloqueio de - que se dá no presente. Pensando na palavra, per-plexo: o que atravessa seu plexo, gerando incompreensão e consequente paralisia. Se o trauma do barulho das cabecinhas estourando acompanhou Souza, seu imobilismo diante da prisão de um cientista, que marcou a abertura do tempo em que vivia, também.

Fomos ingênuos. Como eu, muitos. Tínhamos nas mãos posições através das quais era possível, lentamente, instilar um gesto de lucidez, um pouco de consciência. Semente de inquietação. [...] 
Sim, aquele cientista protestou. Teve coragem. Quem lembra seu nome hoje? Havia na universidade um livro negro. Intenso relato da perseguição que professores, pesquisadores, médicos, cientistas, sofreram. Até o momento em que os registros não adiantaram. A exceção virou normalidade. Convivemos com ela, nos habituamos. O cientista punido não me sai da cabeça. Eu estava no hall da universidade [...]. Ao passar por nós, no hall, parecia o mesmo homem de todos os dias. Nem a cabeça abaixada, derrotado. Nem erguida, sinal de orgulho e indiferença. Homem normal. Tinha acabado de perder seus direitos. O de professor, o de circular, comprar, conversar com os outros. O de viver, enfim. Eu estava chocado. Não fazia ainda ideia exata do que se abatera sobre aquele homem. [...] No entanto, ele se ergueu. Sua voz indignada clamou. Contra o deserto. Não calculávamos os resultados. A reação foi violenta. Deixou-nos confusos. [...] A punição daquele homem foi a chave que nos forneceram, o aviso. Não a utilizamos. Levei alguns meses perplexo, até a vergonha tomar conta de mim. Senti que devia ter atravessado o hall e me colocado ao lado do professor. Tivéssemos todos feito isso, algo poderia ter mudado. [...] Dar as mãos simbolicamente. Penso muito nisso. Já se passaram tantos anos e ainda me imagino. Nós, juntos, diante da universidade. Ou aniquilavam todos, ou voltavam atrás. Permitimos. Não me conformo. Culpa que carrego. Ela me corrói. Nada pior que a memória de um gesto não realizado (BRANDÃO 1982, p. 60-61 - grifo nosso).

A lembrança do não feito de Souza o acompanhava. A perplexidade, a paralisia, que gerou uma memória dura. Ainda era possível? Desde o furo que apareceu na mão de Souza, perpassando toda a sua narrativa, memórias mais ou menos semelhantes a relatos factíveis e delírios aparecem na obra. Delírios traumáticos, delírios de esperança. A sensação de sede que acompanha o leitor na leitura, o calor, vai dando espaço ao desejo de chuva. As Grandes Marquises: promessas do Esquema para acabar com a incidência do sol. Na realidade, um grande galpão, um depósito de gente que, no fundo, aguardava a morte. Mas no meio do cinza, no meio do concreto, onde não tinha vida e a sobrevida esperava a hora da morte, Souza pôde ver nascer um broto. E junto ao broto, veio o cheiro de chuva. Ele sentiu cheiro de chuva. Ele sentiu o cheiro de chuva? 


\section{(In)Conclusōes}

Afirmando não desejar fazer de Atmosfera, Ambiência, Stimmung (2014) um tratado metodológico, Gumbrecht caracteriza como secundária a tentativa de captura, em artigo científico, da atmosfera que emana de uma obra e que acontece em nós, leitores e leitoras. Entretanto, o objetivo desse trabalho foi buscar realizar uma amálgama entre a interioridade e a exterioridade da obra, percebendo os afetos que emergem de Não Verás.... Se Gumbrecht não resolve questões, ao menos as coloca como potência. É possível que a atmosfera de pestilência, de perplexidade e de esperança que envolve a interioridade da obra tenha relação com uma mesma atmosfera que envolvia o autor e seus contemporâneos no momento da escrita? É possível, ainda, que a leitura contemporânea da obra seja capaz de afetar leitores no presente-hoje?

Embora o futuro que construiu Ignácio de Loyola Brandão seja, de pronto, distópico, em entrevista concedida em $2008^{7}$ o autor paulista confessa preferir pensar que se trata, na realidade, da projeção de uma utopia. Entre profecia e aviso de incêndio, os anos 2010, 2020, 2030 do Brasil que escreveu em suas páginas era um futuro possível e provável, embora não desejado pelo autor. Tanto no enredo principal como em detalhes nos entremeios da trama, é possível perceber brechas onde, com um fio de luz, pode se enxergar esperança. Mas também se pode não. Se Souza viu o broto ou não, se o cheiro de chuva era real ou não, o autor preferiu deixar que os leitores decidissem. O não fechamento da obra pode configurar-se na tentativa de sua perenidade para os próximos anos? Otimista autodeclarado, utópico em um momento de falência das utopias, o broto que Ignácio criou na obra seria também um broto criado na realidade fora da obra através da obra? Quero dizer: Ignácio fez da obra o próprio broto?

Se não é possível nem é intenção estabelecer uma relação direta entre as situações de trauma, perplexidade e esperança vivenciadas por Souza e seus leitores da década de 1980, talvez seja possível pensar que a atmosfera pestilenta, a atmosfera 
da perplexidade e da esperança fossem ares que respiravam os contemporâneos de Loyola. Entre pessimismo e otimismo do autor, questões ficam abertas no decorrer do livro, cabendo ao leitor fechar (ou não) os pontos abertos. Souza teve mesmo filho? O navio afundou? As cabecinhas estouraram? O furo existiu ou é metáfora para a angústia de Souza? Souza viu o broto nascer onde a vida não era possível? Souza era o próprio broto? Existe, ainda, possibilidade de vida brotar? E a chuva, vai chegar...? Entre repressão e liberdade, fechamento de futuro e possibilidade de ação: decidam os leitores com base nas suas próprias crenças otimistas. Ou não.

\section{REFERÊNCIAS BIBLIOGRÁFICAS}

AGAMBEN, Giorgio. Estado de Exceção. 2a ed. São Paulo: Boitempo, 2004.

ARAÚJO, Valdei L. e RANGEL, Marcelo M. Teoria e história da historiografia: do giro linguístico ao giro ético-político. In: História da Historiografia, n. 17, 2015. p. 318- 332.

BORGES, Nilson. A doutrina de Segurança Nacional e o governo dos militares. In: DELGADO, Lucilia de Almeida neves; FERREIRA, Jorge (orgs.). Brasil Republicano: $O$ tempo da ditadura. Vol. 4. 7a ed. Rio de Janeiro: Civilização Brasileira, 2014. p. 13-42.

BRANDÃO, Ignácio de Loyola. Zero. 7. ed. Rio de Janeiro: Codecri, 1980.

. Não Verás País Nenhum: Memorial Descritivo.

Rio de Janeiro: Codecri, 1982.

BRASIL. Ato Institucional no 1, de 9 de abril de 1964. Dispõe sobre a manutenção da Constituição Federal de 1946 e as Constituições Estaduais e respectivas Emendas, com as modificações introduzidas pelo Poder Constituinte originário 
da revolução Vitoriosa. Diário Oficial da União: 09 de abril de 1964. Disponível em: <https://goo.gl/k3FLPb>. Acesso em: 28 jul. 2017.

BRASIL. Decreto-lei no 314, de 13 de janeiro de 1967. Define os crimes contra a segurança nacional, a ordem política e social e dá outras providências. Diário Oficial da União: Seção I, 13 de janeiro de 1967. p. 2993. Disponível em: <https://goo.gl/yAxwFL>. Acesso em 28 jul. 2017.

CALIL, Mário Lúcio Garcez. O direito fundamental à memória e à verdade e a justiça de transição: pressupostos para a construção de uma cultura constitucional democrática. In: Justiça de Transição para transição da justiça. Porto Alegre: Editora Acesso, 2012. p. 137-164.

CALVEIRO, Pilar. Poder e Desaparecimento: os campos de concentração na Argentina. 1a ed. São Paulo: Boitempo, 2013.

CATROGA, Fernando. Memória, História e Historiografia. Rio de Janeiro: Ed. FGV, 2015.

DERRIDA, Jacques. A estrutura, o signo e o jogo no discurso das ciências humanas. In: Escritura e Diferença. São Paulo: Perspectiva, 1971.

GUMBRECHT, Hans Ulrich. Atmosfera, Ambiência, Stimmung: sobre um potencial oculto da literatura. Trad. Ana Isabel Soares. $1^{a}$ Ed. Rio de Janeiro: Contraponto: Editora PUC-Rio, 2014.

LAPLANCHE; PONTALIS. Vocabulário da Psicanálise. 4a ed. São Paulo: Martins Fontes, 2001.

NIETZSCHE, Friederich. A genealogia da moral. Trad. Attila Blacheyre. $1^{\text {a }}$ ed. Rio de Janeiro: BestBolso, 2006.

PANDOLFI, Dulce. Depoimento. [28 de maio de 2013]. Rio de Janeiro: Comissão Estadual da Verdade. In: BRASIL. Comissão Nacional da Verdade. Relatório final, volume 
II. Capítulo 10, nota 17.

SAFATLE, Vladimir; TELES, Edson. (orgs.). o que resta da Ditadura. $1^{\text {a }}$ ed. São Paulo: Boitempo, 2010.

SILVA, Antônio de Pádua Dias. A cidade deteriorada: distopia e ecologia na ficção de Ignácio de Loyola Brandão. Terra Roxa e Outras Terras, v. 12, p. 5-15, 2008.

\section{AGRADECIMENTOS E INFORMAÇŌES}

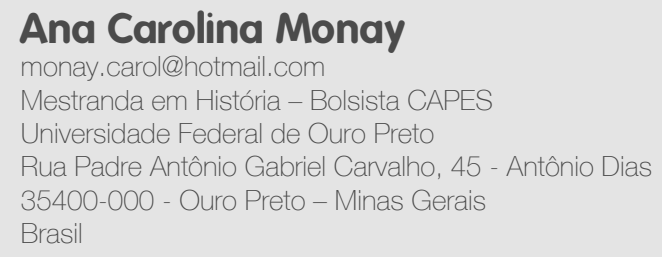

Ana Carolina Monay é graduada em História pela Universidade do Estado do Rio de Janeiro (2016) e, atualmente, mestranda do Programa de Pós-Graduação em História da Universidade Federal de Ouro Preto. 